\title{
Feminist Culture and Politics in Iranian Women's Post-Revolutionary Poetry (1979-2017)
}

\author{
Mahrokhsadat Hosseini ${ }^{1 *}$
}

Published: March 19, 2018

\begin{abstract}
This article shows how Iranian female poets in the post-revolutionary period, through their poetry, transgress several socio-cultural boundaries. The strategy of these women poets is the same: to become more visible, to raise their voice, to resist and to create a new identity not far off from their self. The article shows how the Iranian women poets in question attempt to promote ethical relations between human subjects through using their feminine writing. Their poems highly criticise an Iranian historical tradition that does not sufficiently recognise the presence of two different subjects - masculine and feminine - and which is not concerned enough with the ethics of relations between subjects. These poems can be analysed in terms of an Irigarayian framework that argues for a woman's ability to establish herself as an independent subject. The Iranian authors/poets started to reform and rethink gender, and their poetry opens doors to Bakhtinian dialogism and eventually Iranian feminism. The article argues, using Irigaray, that it is essential for Iranian women to create a "house of language", a place in which they can practice living and articulating, so that they can achieve self-enunciation.
\end{abstract}

Keywords: phallogocentric, self-enunciation, dialogical, deconstructionist, feminine syntax

\section{INTRODUCTION}

Gender-related themes began to be highlighted in women's literary discourse in Iran during the postrevolutionary movement, after 1979. Women's poetry enacted a shift in discourse, from traditional Islamic themes of mothers, wives, guards of the revolution, warriors, and martyrs, to more directly gender-related themes in the past three decades after the revolution.

Gender identity in Iran cannot be detached from the concept of sharm $^{1}$ (self-erasure). Self-control in behaviour and appearance, and confinement of physical mobility and sexuality, are all features of the gender politics in Persian classical poems. These restrictions often function through the concept of self-erasure, or the Persian equivalent, sharm, which is a patriarchal measure of a woman's attraction and beauty (Milani, 1992: 52). It can be argued that the question of sharm was the focus of poets' critical inquiry during this period. Classical poems were created as love poems for and about women, who were at the centre of the poetry, an aesthetic object, there to be gazed at (ibid). In other words, these poems predominantly had a monologic voice and were produced from the perspective of the masculine lover only. However, the women poets in post-revolutionary period gradually attempted to challenge the question of sharm and remove the position of woman as beloved, and transferred this position or direction of the poem into men to be gazed at.

The present study proposes a fresh evaluation of contemporary Iranian women's poetry. It adopts a feminist theoretical context in order to observe the shift in women's poetry from the concept of sharm (self-erasure) to more recognisably feminist themes. It looks at the nuances of the relationship between femininity and masculinity, and offers a 'self-enunciation' of the female other in the context of Iranian culture.

\footnotetext{
${ }^{1}$ The concept of sharm in Iranian culture applies typically to women and it is recognised as a modesty aspiration for women. According to Rouhi Shafii in Scent of Saffron (1997), the concept involves both an internal state and an external behaviour. It is associated with feelings of embarrassment, shyness or self-restraint and a women's public self-erasure. In this research, I will focus on the self-erasure aspect as a denotation of captivity within a phallogocentric order.
}

${ }^{1}$ University of Sussex, Brighton, UK. Mahrokhsadat Hosseini is an independent scholar and poet who completed her $\mathrm{PhD}$ at the University of Sussex, UK, in 2017.

*Corresponding Author: mahrokh_hosseini2000@hotmail.com 
This paper will analyse post-revolutionary women's poetry in Iran in order to reveal how the poems express sexual desire regarding notions of visibility and invisibility, and how they modify male mythologies into ones from a female point of view. Moreover, the study will identify how, despite the state's censorship practices, female authors have found ways to escape the restrictive rules in recent years by targeting their readership via digital media. The paper focuses on the poetry of Tahereh Saffarzadeh (1936-2008) and Granaz Moussavi (1974- ), published in the three decades after the revolution, and documents a shift in their discourse from traditional Islamic themes as mothers, wives, protectors of the revolution, warriors and martyrs, to more gender equality themes. These two poets could offer a range of ways in which Iranian female poets voice critiques of existing gender norms during these three decades. Tahereh is from an older generation of female poets whose writing belongs both to the prerevolution and post-revolution period. Granaz is from the younger generation that did not experience the period before the revolution, but her upbringing overlapped with the constitution of Islamic Revolution and its upheavals.

In this search for the cultural meanings of contemporary Iranian women's poetry, the French feminist Luce Irigaray's transcendental theories of the duality of subjectivity, the masculine and feminine, and the culture of dialogic exchange between different subjects, will inform the reading of the selected poems. Using such Irigarayian modes of resistance, I will explore how the two poets transformed traditional poetry in order to represent certain female experiences in their culture. I will demonstrate that women poets of this period oppose masculine authority over language and reverse the negative image of women, through literary strategies that can be understood in terms of Irigaray's resistant praxis and her three phase division of oeuvre (Olson, 1995: 145). In other words, I will show how Irigaray's division of work to three phases can be used to open up and explore the poetry: the first phase is to criticise the auto-monocentrism of the symbolic subject, the second is to define a second subject, and the third is to define a relationship or an ethic between the two different subjects. My analysis of post-revolutionary women's poetry will attempt to establish whether the female poets of this period seek to cultivate and embody the female subject and simultaneously return to the reality of existence of two subjects.

Forough Farrokhzad (1935-1967) is considered to be the pioneer of the female poets who initiated writing about the erotic elements of the female body in Iran. But after the revolution, other female young poets such as Granaz, continued to insert these erotic elements into their poetry. They provide reflections on the first, second and third phases of Irigaray's work, show how two sexually different subjects can survive by creating a third space, and explore the possibility of parler femme by embodying a 'house of language' in their feminine syntax. It can be argued that the project of writing about the body in feminist poets' work, such as the poetry of Granaz Moussavi, to borrow Irigaray's words, 'upsets the linearity of a project, undermines the goal-object of desire, diffuses the polarisation toward a single pleasure, disconcerts fidelity to a single discourse' (Irigaray, 1985: 30). In doing so, they resist typical arrangements of male sexual desire. Their work does not follow the traditional Iranian narrative pattern of experiencing pleasure: arousal, tension, climax and resolution (ibid: 133). Instead, these poets appropriate language to represent a female sexual pleasure that opposes and reverses the linearity of male pleasure. Female desire in their work contradicts traditional logic and disorders syntax. These feminist poets adopt an associational eroticism that forms their poetic diction and expression, to articulate a female desire, a desire with multiple endings and beginnings, multiple orgasms, multiple voices, multiple patterns of female sexual pleasure.

\section{METHODOLOGY}

There is still a persistent need for a systematic and comprehensive theoretical approach to women's poetry in dialogical ${ }^{2}$ terms, and a consideration of the ethical ${ }^{3}$ questions in literature that relate to women in Iran. Feminism in Iran is a term used to describe Iranian women's struggle for gender equalities and their resistance to patriarchal system. However, the term might be misinterpreted with Western connotations by both the secular and Islamic feminists. Much of the misunderstanding takes place simply because the term feminism does not have a Farsi

\footnotetext{
${ }^{2}$ Irigaray refers to two epistemological models in conceptualising ethics: 'monological' versus 'dialogical' consciousness. Irigaray stresses the dialogical model of the 'two' rather than the monological mode of the one (one is man, and the other is woman who is an autonomous and different subject [ ] (1993:48). The monological model of subjectivity according to Irigaray is historically masculine and the one does not take the other seriously since he views the other as 'things' to be exploited. Irigaray endorses the paradigmatic model of two autonomous and different subjectivities, masculine and feminine, in order to ensure and promote dialogue and intersubjectivity to facilitate their coexistence.

${ }^{3}$ For Irigaray, the psychoanalytic gesture is the start of an ethical relation to the other and not the conventional meanings of ethics. Irigaray's text An Ethics of Sexual Difference is devoted to this theme. She believes that it is unethical that women have not had access to subjectivity, and that the universals of our culture have been dominated by a male imaginary. She says that ethics requires that men and women understand themselves as embodied subjects. She argues in her text that men and women must work together to learn to respect the irreducible difference between them.
} 
equivalent and is extensively exercised as a Western meaning in Farsi that is understood as sexism, a discrimination or devaluation based on a person's sex. The nature of relation between Islam, Human Rights and Feminism is one of the most important contemporary issues in Muslim cultures.

Many Muslim, Islamic and secular feminist groups in Iran experienced a problematic relationship despite similarities in their procedures. Ziba Mir-Hosseini argues that women in Iran who adopted principles and ties to feminism have experienced a constant struggle as Muslim women since secular feminism argues that women's emancipation is impossible under such a theocratic government as observed in Iran. The Muslim aspect of their identity is sometimes simplistically described by secular scholars as oppressed, whilst their feminist identification is perceived as 'progressive and emancipated,' (Mir-Hosseini, 1999:14). The same question is central to debates surrounding Islam and feminism or more recently, within Islamic Feminism. Western Feminism is seen by some Muslims as 'one of the many instruments of colonialism. They despise the kind of freedom offered to women in the West' (Afshar, 1996: 200). I believe an approach by scholars analysing literary works concerning a woman's ability to establish herself as an independent subject can be more effective in overcoming such problems in a state where openly feminist movements are not acknowledged and the activists' measures are foreclosed.

Along with feminist activists in Iran, women who were active in the literary fields also showed a great inclination towards feminism, e.g. some poets as feminists engaged in activism through their poetry. Literature became women's central medium of self-expression and an important means for them to illustrate their suppressed voices.

I mainly borrow my approach from the work of Irigaray and will survey the poets' use of techniques for shifting the situation of women in Iranian culture. Mimesis, strategic essentialism, utopian ideals, and employing novel language are some of the techniques central to this poetry and its attempts to change contemporary culture and highlight ethical relations. There are not enough studies that use Irigaray in connection with any theoretical, linguistic, spiritual and artistic practices in Persian literature, specifically in relation to women's work, however Irigaray draws heavily upon writers such as Bakhtin, who is very popular in Iranian intellectual tradition. In hoping to develop a gender-neutral point of view studies in Iran, I believe Luce Iriagary's resistance theories could offer more contribution to current politically controlled feminist movements in Iran firstly to stress the definition of a meaning for an articulating gendered subject, and secondly to recreate those elements of the feminine syntax that are excluded in the traditional discourse of Persian poetry.

I argue that resisting or deconstructing patriarchal discourse is essentially the goal of the selected poets. My argument connects Iranian women poets' literary politics and Irigaray's philosophical (ethical) position in the sense that they mutually involve literary and ethical approaches to work in the concealed space of the other in a phallogocentric world. It is suggested in this paper that Iranian women poets' style forms a parallel relation with the three phases of Luce Irigaray's oeuvre: 'the first a critique, you might say, of the auto-mono-centrism of the western subject; the second, how to define a second subject; and the third phase, how to define a relationship, a philosophy, an ethic, a relationship between two different subjects' (Olson, 1995: 145). These divisions are a very useful guide to understand the persistent development of thought in Iranian women's poetry. These phases or continual shifts will show how the poets stress the importance of the need to replace the duality of subjects in sexual difference, with the singular masculine one.

During the last few decades Luce Irigaray's work has been studied from several standpoints. Her writings have been analysed both by those feminists agreeing with her work and by those who are more critical of her understanding of philosophy and psychoanalysis. The diversity of perceptions of Irigaray's work results in the classification of her work according to four common attitudes: Irigaray as a biological essentialist, Irigaray as antifeminist, Irigaray as deconstructionist, and Irigaray as heterosexist. I acknowledge Irigaray's methodology of revealing the repressive mechanisms present in the socio-symbolic order, mechanisms that deny the female subject. A key element in her theory contends that written language confines the feminine into a phallogocentric logic. Although I am fully aware of the possible essentialist, anti-feminist and other charges against Irigaray's work, in this paper I want to stress the aspect of Irigaray as a deconstructionist, rather than focus on the other charges against her thought.

This article does not suggest that Irigaray is a truly inclusive theorist nor does it attempt to read all aspects of the poems using her ideas. However, since deconstructing stereotypes from within is the aim of Irigaray's work, her thoughts can be linked to Persian women's poetry as an approach aimed at uncovering masculine phallogocentric practices and their method for the elimination of the female subject in the patriarchal culture.

Moreover, Irigaray does not argue for a writing of the female body; she argues for the need to speak the feminine, to articulate it and to give it room for enunciation. To speak the feminine is more influential for Irigaray because according to Irigaray feminine language is derived from the patriarchal pre-oedipal period of fusion between mother and child (Irigaray, 1989:132). Poetry arguably provides a cultural arena in which to begin to explore these ideas and to put them into practice. Irigaray believes the language of poetry is a form of dialogue that is more suitable than a 'speculative' way of speaking. She writes that, in speculative language, 'I talk the other's language, using his grammatical and lexical norms' (Irigaray, 2004: 47). The selected poets’ work in this study could 
offer such a platform to challenge masculine grammar, and the possibility of another syntax which allows for the articulation of female sexual desire within its diffusive language.

\section{TAHEREH SAFFARZADEH (1936-2008)}

\section{Early Work}

Tahereh Saffarzadeh is one of the most prominent Iranian female poets; her work falls into both the Pahlavi (her first collection was published in 1960s) and post-revolutionary periods. It can be argued that Tahereh's prerevolution poetry encompasses all three elements of Irigaray's schema, but her post-revolution poetry doesn't follow that representation so much. In her early work before the revolution, Tahereh challenges existing gender norms such as women's oppression and seclusion. Tahereh's poetry is a good example of literary reflection upon the socio-political changes in Iran. She expresses the impact of socio-political transformations on women's identity and creativity. Solitude, alienation, the search for autonomy, anger and confrontation with patriarchal social structures can be considered the common themes of the first period of her work. In her early poems Tahereh seeks to liberate herself from restrictive social codes and conventions. In her first collections, she undertakes a process of self-discovery; this ends with her trip to England (1967) and later to America (1969). The poems of her first collection, Moonlight Passer-by, composed from 1956 to 1962, are mainly in the form of love lyrics focusing on the poet's experience of alienation and solitude.

The image that Tahereh is sharing through her poems in the first period is of the poetic persona's dilemma and dissatisfaction, to the point that she finds comfort and freedom only in companionship with God and poetry. In her later works, this connection becomes more evident, and Tahereh began to write poems on topics such as birth, death, love and injustice. In her early work Tahereh is openly present in the poems, and there is not much distance between her and the personas in the poems. She is not proscribing her inner feelings and where she feels the necessity, she expresses them. Milani ${ }^{4}$ suggests that 'the author seeks freedom that slips through her [Tahereh's] cupped fingers. Alienation, fragmentation, and a search for autonomy are by far more forcefully realised here than is the ideal that the poet longs to compass' (Milani, 1992: 161). In her early collections, Tahereh challenges social codes and norms. According to Milani none of the female characters of the poems in the first collection feels the 'solace of conformity or domesticity; instead they experience a dilemma in its crudest form' (ibid).

The second period of Tahereh's work began when she left her job, loses her child and leaves Iran to continue her education in the USA at the University of Iowa. Her fifteen English ${ }^{5}$ poems in the collection Red Umbrella (1969), published by Windhover Press, give the impression of her new style. The poems challenge the masculine culture of her period. She shows her dislikes and expresses her seclusion from norms, anger and distinctiveness. The poems here are feminine, sensual and erotic, while directly questioning of Iranian patriarchal values. According to Tahereh's own words, her experience of living in America, getting to know foreign poets and her interaction with other artists had a great influence on her thinking (Saffarzadeh, 1979: 131). The content of Tahereh's poems in this collection expresses the persona's eccentric experiences and desire for more. This open, spontaneous space enabled the poet to expose her emotions and inner self without the need for conformity to social standards or moral codes. She challenges the concept of sharm (self-erasure) in her collection, and expressions of sensual and erotic themes are not concealed.

However, this did not last long and her language and content changed after her return to Iran. It can be argued that the poet's being away from home, having a different type of audience and readers, as well as writing poems in English, detached her from the intolerance of the source language and its implicit restrictions that she adopted in her previous collections. She left the sense of captivity in her early poems and decided to attack society's injustice towards women. Her poem 'My Birthplace' (Zadgah), from her collection, Tanin Dar Delta (Echo in Delta) (1971), expresses the poet's anger toward cultural discrimination in Iran. She illustrates the moment of a girl's birth and the relation between mother and daughter. Tahereh condemns the mother's silence and immobility and her failure to confront tradition:

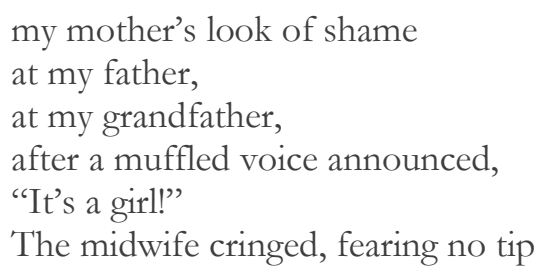

\footnotetext{
${ }^{4}$ Farzaneh Milani is an Iranian-American scholar and author. Milani teaches Persian literature and Women's Studies at the University of Virginia.

${ }^{5}$ Tahereh was the first Iranian female poet to have a collection of her poems originally published in English.
} 
for cutting the umbilical cord,

knowing there'd be none

for circumcision.

On my first pilgrimage to my birthplace

I will wash from the walls

My mother's look of shame[.]

(Milani, 1992: 164)

Tahereh presents the mother and the newly born girl as victims of patriarchal practices and values. She refers to the relationship between mother and daughter that is damaged by patriarchal society. The need to modify the mother-daughter relationship is also a constant theme in Irigaray's work. In this poem whereas the mother's role is shown as passive and immobile, her persona's voice is loud and critical. To show her resistance and opposing belief, the persona refuses and discards masculine supremacy and looks for a new identity distinct from her mother's:/ I will wash from the walls/ My mother's look of shame/. Traditionally and for a long time, families in Iran regarded having boys as more desirable. Some documents from the Achaemenid period (550-330 BC) show that mothers with baby boys were adored more compared to ones with girls. Midwives and medical practitioners were given more payment for delivering baby boys (Hamidpour, 2010: 48). Tahereh's poem illustrates these moments of suffering, the whispered and muffled voices, the depressed and shameful feelings of the mother and the midwife won't be paid: / The midwife cringed, fearing no tip/ for cutting the umbilical cord/. Its tone echoes the overpowering masculine culture.

The persona in the poem does not merely express her grief at the injustice in her culture. She also has a critical and mimetic voice that confronts discrimination. The figurative passage into the tradition here is not to authorise the past, but to invert the condition that makes women feel shame and suffering at the birth of a baby girl. Tahereh presents a female poetic persona who refuses to be of a similar status as her mother and who seeks her own equal importance and value. She challenges the relationship between mother and daughter in her poem and, similar to Irigaray, she is looking for a 'rehabilitation' of the relationship between mother and daughter, in order to recuperate her/self. By reconstructing the normative practices of motherhood, Tahereh's poem provides awareness that helps re-imagine female consciousness and thereby begin intervention, aiding women in becoming subjects of resistance who can confront the dominant authorities.

In other words, the poet's strategic use of the relationship between the mother and daughter (mother-daughter relationship) is a form of deconstruction of normative models of women's compliance to men's desire, and simultaneously a reforming attempt at establishing a new, liberated place for women in society. In Je, tu, nous (1993) Irigaray proposes techniques to deploy for improving the relationship between mother and daughter. For instance, exposing images of the mother and daughter together, or deliberately stressing the subjectivity of each of them. The poet here portrays the daughter's position relative to her mother. Displaying images of mother and girl together in this poem illustrates the need to alter the mother/daughter relationship that is a persistent theme in Irigaray's work.

Irigaray stresses the need for mothers to symbolise themselves differently to their daughters, and to emphasise their daughter's separate subjectivity. Tahereh, by embodying the picture of mother and daughter, reminds women of their lack of subject identity, since the female identity is 'imposed upon her as pure exteriority' (1996: 47). To challenge the relationship between the mother and daughter in this poem, the poet refers to a free and active woman who has the ability to choose her own path and future. This new meaning for the relationship is in opposition to the masculine characterisation of the undifferentiated relationship between mother and daughter. Tahereh's representation of this relationship grants autonomy to women and encourages them to take action and to reconstruct their own identity.

Similar to Irigaray's technique of mimetic resistance, Tahereh first illustrates the traditional and normative Iranian culture that shows the most desirable child for a woman is a boy, into whom, according to Irigaray, she shifts 'all the ambition which she has been obliged to suppress in herself' (Irigaray, 1985: 14). Women's value according to this normative culture depends on successfully giving birth to a male child. The poet shows how this masculine culture provides detailed descriptions of the mother-son relationship, but ignores the mother-daughter relationship. Irigaray argues that, unlike the son, the daughter is not recognised and privileged in her society and is 'kept as a natural body good only for procreation' (Irigaray, 1993: 46).

For Irigaray, for a girl to recognise her individuality and self-enunciation is for her to have a possibility to escape from the patriarchal order and attain her own separate subject position. Therefore, the mother should resolve their relationship and assist her daughter in becoming a separate, individuated subject. Irigaray states that: "When I speak of the relation to the mother, I mean that in our patriarchal culture the daughter is absolutely unable to control her relation to her mother. Nor can the woman control her relation to her maternity, unless she reduces to that role alone" (Irigaray, 1985: 143). The mother-daughter relationship in Tahereh's poem is an attempt to 
create a new discourse and replace the normative pattern. Tahereh removes the boundaries and restrictions between the mother and daughter figures, in order to give voice to women in Iran and mobilise their potency.

The second period of Tahereh's writing is infused with Western values absorbed in England and the USA. She was criticised in this period for using too many foreign words and too much Western ideology in her poems (Milani, 1992: 158). However, Tahereh's stance shifts once again in the second part of her collection, Tanin Dar Delta (Echo in Delta), and themes of spirituality and Islamic topics, as well as views opposing Western influence in the social and political domains, start to appear more frequently. When she deploys Islamic topics in her poems she has a new interpretation of them, however.

Milani states that Tahereh 'finds an invigorating ideology of freedom and equality' in Islam and prescribes it as a 'revolutionary banner to mobilise people' (Milani, 1992: 167). It can be argued that the impact of feminist consciousness is exposed in Tahereh's poem, and that it shows the beginning of new activities or a discursive shift in women's poetry, especially for Islamic poets after the revolution, which female poets of the past did not reflect in their discourse. Although these Islamic authors did not apply gender-related statements in their work, they did occasionally add to the body of women's discourse by reinterpreting Islamic norms.

In other words, Tahereh's poetry in the years just before the revolution takes swift steps to connect with Islamic themes. For Tahereh, Islam becomes the ideology of resistance to the West, and of seclusion from society, monarchy and autocracy of the Pahlavi dynasty. As Milani states, Tahereh found the religion 'as the sole viable cure for all the ills and affliction of her society and voluntarily veils herself (Milani, 1992: 167). Whereas in Tahereh's early poetry, religion had a personalised impact, in her subsequent poetry it became an effective tool in building her ideal society.

\section{Post-Revolutionary Work}

Tahereh's third period of post-revolutionary work makes a transition from her early work toward her full compliance with religious themes and the literature concerning the Islamic revolution (Adabiyat-e Engelab-e Farhangi). Throughout this period, her style did not obey Nimaic rhythms or any traditionally structured rhythmic design, she used a more controlled tone. While she expressed her inner feelings more openly in her earlier poems, here she demonstrated more restraint by using a measured, metaphorical and ironic language.

The practice of veiling after the revolution became mandatory in Iran. The veil was mainly advocated as a political campaign to resist the Westernisation, which was considered one of the reasons for the supposed moral corruption in Iran. By the late 1970s, for many women, such as Tahereh, the veil represented what the Pahlavis had rejected: from a symbol of oppression and a badge of backwardness, it was transformed into a marker of protest and of a new Islamic identity (Mir-hosseini, 2007: 7). As Tahereh began to practice veiling willingly, her poetic persona also started to veil her outraged feminist voice. It was as if she blocked her poetic personas' sense of the search for self-enunciation and Western style of personality that had marked her poetry in the Pahlavi period, and instead replaced it with a new sense of cultural identity. This new shift in Tahereh's poetry seems distant from the ideas and practice of individualism and women's rights. It is more about religious obligations. In these poems, she indicates her support for the elimination of Western elements and intervention. In contrast to her earlier collections, her poems after the revolution do not resist the patriarchal system in society. For example, in the collection Beiáat ba Bidari (Allegiance to Wakefulness), published during the Iran-Iraq war in 1987, Tahereh praises Ayatollah Khomeini as a hero among the prophets and as the soul of God spreading justice:

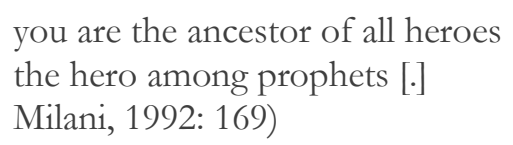

According to Milani, in Tahereh's poetry after the revolution, her women no longer has the desire to rebel against the state's imposed gender restrictions. Milani continues:

Her [Tahereh's] feminist voice is submerged in a neutered persona, if not discounting, then at least hiding her sex behind an asexual facade. In these gender-indistinguishable poems, the peculiarities of the self are transformed, harnessed into the revolutionary social system, where there is no space for personal, especially feminist, demands. One no longer finds any concern over the fate of women, let alone any protest over her condition. (Milani, 1992:171)

\section{Breaking Codes of Sharm (Self-Erasure)}

Although Tahereh's early poems to some extent broke the code of sharm, her post-revolutionary work became neutral and gender-less, composed in the context of sharm. Tahereh's attention to the self and lyrical images of love disappeared and they were replaced by a collective self of religious desire. Tahereh's later work carefully detaches her inner self from her readers. She disguises her gender and has a neutral approach to gender-related subjects. Her critical voice disappears and there is no confrontation with masculine or patriarchally controlled society. Her 
feminist voice, seeking equality for the sexes, is almost non-existent in her later collections. Her enunciation of self has vanished amongst the more dominant voices of the revolutionary society. Tahereh's conformity to the collective voice of society and the gender politics of the period after the revolution could depict the poet's conscious choice of changing her direction of writing under the hegemony of Islamic politics.

Tahereh's work after the revolution, unlike her early work, cannot be read in terms of Irigaray's three phase division. The female personas in Tahereh's later work remain in an 'economy of the same'. But their presence in phallocratic logic does nothing to deconstruct that logic. In such a symbolic order, the female personas have no right to claim their own unique genealogy, beliefs or becoming, and as such cannot enunciate their inner self as a locus for changes to the symbolic order.

For Tahereh, religion was a personal issue before the Islamic Revolution, but after the revolution Sharia laws informed the state's policies and 'it was no longer enough to be just a believer; one had to wear one's beliefs in the form of hijab' (Mir-Hosseini, 2005:1). Tahereh's later poetry stresses religious and political themes and she does not show any resentment toward the reconstituted Iranian state. As advocator of Islamic themes after the revolution, Tahereh is not critical of patriarchal society and she does not excavate the monosubjective (masculine) character and tradition of Iranian culture in this period. Moreover, she does not seek in her poetry to express the conditions necessary to develop a culture of the feminine. Therefore, it is possible to conclude that one cannot really connect Islamic poets such as Tahereh to Irigaray's three phases: to criticise the auto-monocentrism of the symbolic subject, to define a second subject, and to define a relationship or an ethic between the two different subjects.

\section{A VOICE IN EXILE: GRANAZ MOUSSAVI}

Granaz Moussavi (born in 1974) is representative of female poets in Iranian diasporic literature. She is considered to be a member of the young generation of poets after the revolution, often referred to as the 'children of the revolution' or sometimes the 'scorched generation', who experienced the Iran-Iraq war in their upbringing and did not experience a peaceful childhood. Educated in the revolutionised schools, they faced many unanswered political and religious questions and became unconvinced by the authorities' justifications for sociocultural conditions at the time. Granaz is from a well-educated family and she emigrated with her parents to Australia in 1997.

Using a distinctive female voice, she echoes her repressed feelings and seeks other possibilities of political and social articulation, resisting the perceived ignorance of the male-oriented authorities. Granaz's imaginative language and creativity, with strong polemics and a fearless voice, are an example of the range of expressions that exists within women's poetry at present. Although being outside of Iran doesn't necessarily mean free from censorship and cultural normative perceptions or sensitivities, Granaz, unlike poets in Iran, has no limitations on the narration of her poetry to express her uncensored voice. Her distinctive voice can be defined as the spontaneous reaction to her oppressed self with no conscious language restrictions, since she does not need to adhere to the state's political (and repressive) requirements.

Iran's young, post-revolutionary female poets have always struggled with finding a balance between commitment to the modern poetry of poets such as Simin Behbahani and Forough Farrokhzad and developing their own individual style. Granaz is a contemporary Iranian-Australian poet, film director and screenwriter who has developed an original voice in her poetry. Her language is packed with metaphors and erotic images.

Erotic images in a poem do not always involve explicit aspects of sex. Sometimes the poet uses elements related to the description of the sensual aspects of the human body, most typically the female body, to give voice to oppressed women. Granaz signifies feminine jouissance (feminine imagination and eroticism) in her poetry as an implicit strategy. For Irigaray, jouissance refers to the countless forms of pleasure a woman's sensual responsive body can experience. It is not confined to a genital/sexual organ, for example. In other words, Irigaray does not restrict the meaning to acts of genital sexual pleasure. Irigaray argues that "the whole of my body is sexuate. My sexuality isn't restricted to my sex [sexual organs] and to the sexual act in the narrow sens" (Irigaray, 1993: 53). Granaz seeks to challenge the dominance of masculine discourse by writing feminine difference into culture. With the specificity of a feminine jouissance indicated through her poetry, Granaz questions the domination of phallic jouissance, or single pleasure which is explicitly associated with sexual anatomy of a heteronormative masculine subject.

Like Irigaray, Granaz's feminist assessment is focused on the 'sexual indifference' that she finds at the heart of the social order. Granaz's work seeks to deconstruct phallic patterns of imaginary and instead to focus on diffuse female sexuality. By inserting feminine poetic dictions and elements into her poetry Granaz criticises the masculine sexual imaginary for taking feminine pleasure away from discourse. The goal for Granaz, like Irigaray, is to form a place for feminine jouissance, embedded in the erotic and sensual experience of the body. The following poems will demonstrate how Granaz alters the poetic line to enact certain female experiences. 
Irigaray offers a detailed picture of women's pleasure in language. In This Sex Which Is Not One, she argues that woman's desire cannot 'be expected to speak the same language as man's; woman's desire has doubtless been submerged by the logic that has dominated the West since the time of the Greeks' (Irigaray, 1985: 25). A woman has often been classified by lack, the lack of a penis, the lack of reason and the lack of power. Irigaray, however, argues that woman lacks no/thing. She states that "[woman] she finds pleasure almost anywhere. (...) [T] he geography of her pleasure is far more diversified, more multiple in its differences, more complex, more subtle, than is commonly imagined - in an imaginary rather too narrowly focused on sameness" (ibid: 28). Irigaray stresses that women's language can offer them multiple sources of desire:

[In her language,] 'she' sets off in all directions leaving 'him' unable to discern the coherence of any meaning. Hers' are contradictory words, somewhat mad from the standpoint of reason, inaudible for whoever listens to them with ready-made grids, with a fully elaborated code in hand. (...) She steps ever so slightly aside from herself with a murmur, an exclamation, a whisper, a sentence left unfinished (...) When she returns, it is to set off again from elsewhere. From another point of pleasure or of pain. One would have to listen with another ear, as if hearing an 'other meaning' always in the process of weaving itself, of embracing itself with words, but also getting rid of words in order not to become fixed, concealed in them. (ibid: 29)

Female sexual desire in language, then, according to Irigaray, can happen as multiple beginnings, brief poetic dictions, split sentences, nonsensical reasoning and not following consequential, linear patterns (beginning, middle, and end), as well as challenging fixed definitions and views. Female desire in Granaz's poetry collections disrupts the linear narrative model that is prevalent in the conventions of male sexual response.

Granaz's poem, 'Man (I)', from her Sketching On Night collection (1996), is a direct exposure of women's subjectivity and identity crisis:

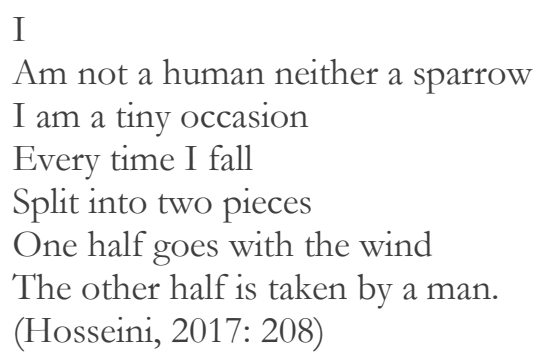

The poem shows how women are not adequately represented by the existing symbolic system in Iranian culture. Borrowing from Irigaray, the poem also illustrates how in the patriarchal world, female subjectivity is based on a lack. The poetic persona explains that women are not given a proper place in this patriarchal world, and that she is in fact not existing either as a human or even as a tiny sparrow. The wind might refer to the norms and standards of society which undermine a woman's identity to form. Finally, we see her as blaming 'a man' for having power over her. Like Irigaray, the poetic persona challenges the fixed definitions related to women's subject position in a masculine society. It states that she has no subject position and is only considered as a tiny occasion: / I / Am not a human neither a sparrow

/I am a tiny occasion/. Irigaray argues that in a patriarchal society 'woman exists only as an occasion for mediation, transaction, transition, transference, between man and his fellow man, indeed between man and himself' (1985: 193). The preference for succinct diction (such as /I/) and fragmented sentences that lack subject or not grammatically ordered (such as: / Am not a human neither a sparrow/ or / Every time I fall/ Split into two pieces/) by the poet represents an enunciation of the female desire to expose the domination of phallic jouissance.

\section{Breaking Codes of Sharm (Self-Erasure)}

In another poem, Aseman Ra Beband ('Close the Sky'), from the same collection, Granaz illustrates a bitter but realistic view about love:

Barbed wire was my mother's dowry

On the border of the road that was reaching the bitter moon

I sleep with you without love

But I get up with more love

Here the bare footed whores

For one pair of shoes and one set of floral china,

Run Mosaddegh to the end of Vali-asr Avenue 
Yes! The air is filled with sick children

Our bed will be recognised

Close the sky[.]

(Hosseini, 2017: 210)

In this example, the poetic persona leaves behind the historical shyness and moral standards that are defined for women, in order to express her loveless life with her male partner. She embodies the conventional sexual relationship that she has to comply with because of the marriage contract. The words 'Mosaddegh' (democratically elected Prime Minister of Iran from 1951 until 1953 when he was overthrown in an Anglo-American coup) and 'Vali-asr' (the title and a synonym for the Twelfth Imam of Shia and the meaning directly attached to the last Saviour; also a name of street in Tehran) are used to indicate the history of women's suffering in a satirical way, as being continuous from the Pahlavi period to the current Islamic period. The female persona gladly announces her freedom from the conventional paths of morality but she pays the price for having done so. Instead of expressing self-restraint and instead of suffering from sexual repression, she gives voice to her fear in the form of physical desire and passion and fearlessly asks to close the window so their bed would not be visible to the opponents.

The poetic persona in the last line gladly makes a public revelation of a sin for which the sentence was death: having sexual relations and children outside marriage. Having children outside of wedlock is forbidden by the authorities and by Islamic laws but the persona inverts this perspective by confirming exclamation expression: 'yes!' Moreover, she attempts to expose the issues related to prostitution and the political subjugation of prostitutes by inverting the commodity value in this phallocratic system. Similar to Irigaray's perception in 'Women on the Market', Granaz reveals the position of use value and exchange value of women in the patriarchal society, in which women are treated in the same way as any other commodity. In the Irigaryian sense Granaz shows that the whore is seen as 'used up' in masculine culture, which makes her a suitable object of exchange for men's desire, without consideration of women's own desire (Irigaray, 1985: 808). The whore in the poem is fully aware of her commodity value in this phallocratic system, and she suffers the pain of being empty. She should run the entire street for her basic needs. The sexual desire of the female persona and a relationship with a man outside the marriage contract, as well as the fear of revelation by the authorities, are reflected several times in different collections of Granaz's poetry. For example, in her poems Rabeteh ('Relationship), Gonah ('Sin') and Baz Ham Gonab ('Sin Again') she similarly expresses her oppressed feelings of desire:

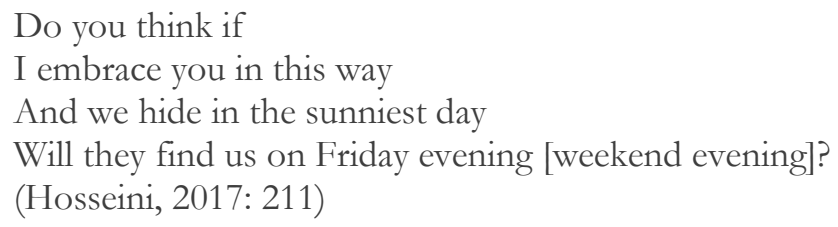

In her second collection, Barefoot Till Morning (Pa Berahneh Ta Sobb) (2000), Granaz continues to transgress the dominant ways in which men and women imagine themselves and each other sexually, and their social space. In her poem Kutah ('Short'), the persona is annoyed at all the oppression and she shows her anger:

Send me a new mirror

My mirror was loaded with my broken images

So it broke.

(ibid)

The female agony and anger in this poem offer an example of what Irigaray might suggest by liberation from forms of masculine artistic dependency and focus instead on the nearly visible world of female culture. The poem is short but steady in movement, full of fluidity and flux. The title of the poem, 'Short', sets up an alternative sequence and initiates a straightforward message. The rhythmical stress on 'mirror', the pronoun 'my' and the word 'broken' sets the poem in motion. The persona's need for a new mirror in the first line establishes a movement from her past identity that was imposed on her by the symbolic masculine order. The broken images of her and the mirror signify a rejection or refusal of the phallogocentric order. There are also multiple presences in the poem by repeating the first subject pronoun. Hence we have a sustained representation of Irigaray's model of female subjectivity: 'within herself she is already two - but not divisible into ones' (Irigaray, 1985: 24). The poem evokes a moment of strong jouissance to describe sheer unrepressed pleasure. As the poem opens up, the symbolic order of language is subsumed within the semiotic: 'new mirror / my mirror / broken images / broken mirror'.

Granaz, like Irigaray, uses masculine models against themselves. If the 'feminine' is an indication of the uncountable figure in the phallic order, then the 'imaginary body', or the reflection, must be masculine. According to Irigaray, since men keep the reflective side of the mirror, then women are the suppressed back part of the mirror, 
holding up the mirror for men. They are not visible in the mirror and have no accurate reflection of themselves. Therefore the poetic persona needs a new mirror to reflect her image and the old mirror must break.

\section{A Novel Feminine Syntax}

Granaz takes the feminine poetic experience further, however, by displaying her writing as an act of embodied jouissance. She expresses a new sensitivity in Iranian women's poetry. This original and different awareness is characterised by selecting simple poetic diction and style to reflect the subjects which are more familiar to the younger generation's experience of life in Iran.

Granaz, similar to Tahereh's poetry written in the USA, finds new opportunities in her exile to Australia in 1997, and her struggle with traditions and norms continues with the articulation of unrepressed feelings of desire and belonging. She starts her collection published in 2000 with the poem 'The Sale', which is a long poem showing the poet's rediscovery of her inner self and the generation she has grown up with in exile. Many works in exile are written concerning themes of being in limbo. The expression and language of these works in exile can depend on the poet's integration into the new country they live in and the diasporic opportunities available to them. However, this sensation of being in limbo in Granaz's poetry creates a new space and language for the poet that is representative of women's contemporary discourse in Iran, and it also displays women's diasporic discourse.

This new language or 'feminine syntax' illustrates Luce Irigaray's definitions of parler femme:

What a feminine syntax might be is not simple nor easy to state, because in that 'syntax' there would no longer be either subject or object, 'oneness' would no longer be privileged, there would be no longer be proper meanings, proper names, 'proper' attributes (...) instead, that 'syntax' would involve nearness, proximity, but in such an extreme form that it would preclude any distinction of identities, any establishment of ownership, thus any form of appropriation. (Irigaray, 1985: 134)

This 'feminine syntax' appears in contrast to the masculine perspective in Granaz's poetry. In other words, parler femme, in her poetry, involves exploring the shape of women's imagination and eroticism, in such a way as to give way to a new poetic discourse in Iranian women's poetry. This feminine syntax is characterised by dislocation of poetic diction, disruptive syntax, apparent disorder, fluidity, repetition and fragmentation. In these poems she offers new meaning to this feminine syntax and offers original perspectives on it by suggesting it as a way to realise the connection between her inner self and her belonging and the fixed, essentialist feminine nature defined by the authorities. The friction between her longing and belonging can be seen in her poems 'Denunciation' and 'Bell', from her collection Barefoot Till Morning. In one poetic persona she refuses to return to Iran and in the other she wants to go back. This theme is repeated in her new collection Red Memories, in the poem 'I want to go back'. These images of longing and belonging are located in much of Granaz's poetry, and they show the poet to be in a discomforting state of limbo. This space of in-betweenness brought a new realisation of the self to the poet. Robert Young suggests that the limbo state 'is the site of enunciation, the instance of every utterance' (Ikas \& Wagner, 2008: 84). In her poem, 'The Sale', Granaz applies the elements of this feminine syntax:

I've wrapped the moon's head in a scarf, slipped the bracelets of the world on her wrists, rested my head on the gypsy sky's shoulder and goodbye... (Talebi, 2008: 161)

Granaz uses a gypsy as the symbol of desire, fluidity, mobility and hope. Here the gypsy also confronts the social boundaries and limitations instituted for women. The gypsy has the potential to shield the persona of the poet and appropriate her with the new possibilities that are open to her gender. Moreover, the poet has changed the subject/object image of the classical lover and the beloved who exists to be gazed at. She also transforms the metaphoric meaning of natural elements, such as a rose with a geranium to convey spring coming:

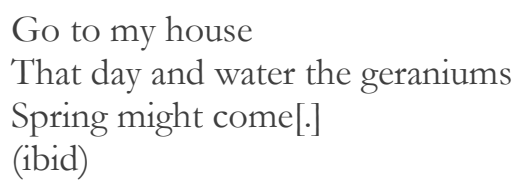

Watering of the flowers is a necessary precondition for the arrival of spring, and it has a direct relation to the reawakening and renewal of the persona. The classical metaphoric meaning of other elements, such as the moon, has also shifted from the symbol of the attractiveness of the beloved, to virginity and pureness. Whereas she leaves the country on the shoulders of a gypsy, she pictures a return to her country and meeting her lover under the escort of the moon: 


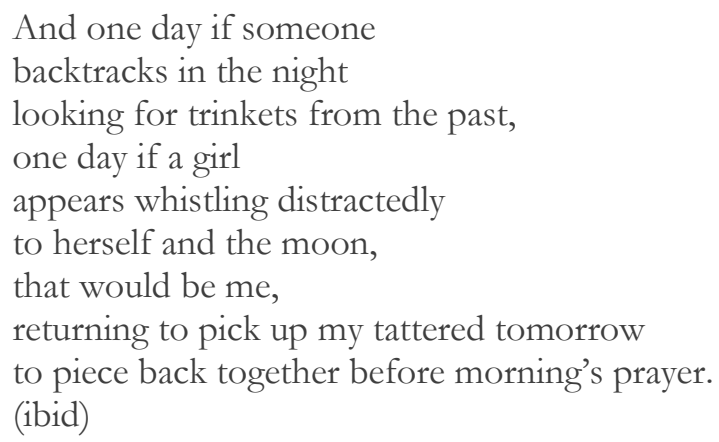

In other words, Granaz utilises the natural elements to give voice to the persona's self-enunciation in classical metaphoric discourse, and she explores these creative feminine syntaxes to help her to find a way to parler femme.

In addition, the poem is written in a non-linear temporal structure, and the tenses (past, present, future and a future that could have been) are non-sequential because of the conditional tense ('if') in the poem. This is to show the status of the persona and perhaps the poet in her exile. However, only by being next to the moon can her return become possible.

On the whole, the creation of a feminine syntax is one of the characteristics of Granaz's poetry. Her first four collections of poetry are expressive of a younger generation after the revolution in Iran, whom she has grown up with and experienced the war with, and shared political and religious reinforcement with. However, in her latest work, 'Red Memories', Granaz shifts her approach of writing about the sufferings of her generation and uses a more personal poetic diction to further develop a feminine syntax, by using natural elements to transgress the masculine culture (Hosseini, 2017: 214). The concept of parler femme in her poetry provides a fresh discourse which allows for the possibility of the continuity of the female persona's existence and self-enunciation. Granaz announces her belonging to nature to give a voice to her invisibility, immobility and non-existence. By employing a novel language, particularly in her latest collection, similar to Irigaray, Granaz uncovers the absence of a female subject position in Iranian culture. Granaz seeks to revalue Iranian female identity and, similar to Irigaray, challenge the existing images with which women were traditionally classified. She challenges the validity of the conceptual hierarchy which favours a metaphorically masculine culture over a metaphorically female nature.

\section{CONCLUSION}

The poetry of Tahereh Saffarzadeh and Granaz Moussavi show a shift in their discourse from traditional Islamic themes as mothers, wives, protectors of the revolution, warriors and martyrs, to those associated more with gender equality during the three decades after the revolution. Female sexual desire appears in the language of their poetry as multiple beginnings, succinct diction, fragmented sentences, and illogical reasoning, as well as a refusal to follow sequential patterns, and defiance of fixed definitions and positions.

These two poets as feminists engaged in activism through their poetry but the degree of their stress on this issue is different. Feminist poets' work inside the country such as in Tahereh's early period poems challenged gender roles, criticised questions of gender inequality, particularly, and they changed their forms and thematic concerns. But the intensity and impact of their work is very different from the younger generation's voice, which is more directly furious and outraged by gender oppression. Moreover, the younger generation's ease of access to online social media made their stance more visible than the previous poets.

Young poets in diaspora, such as Granaz, escaped from the frequent censorship in Iran and became more successful in representing this shift in women's discourse. These exiled poets could concentrate on the elements required to share the culture of two and cultivate the hospitality between the two more explicitly when compared to the female poets inside the country, or the female poets of previous generations. Self-publishing poets such as Granaz, have in recent years used the digital world to distribute their poetry collections, and due to censorship in Iran this has become a trend amongst many feminist poets who want to unveil their voice.

Therefore, it can be argued that power structures, conventional religious beliefs and social values in each period had a direct relationship upon the production of women's poetry in Iran. Finally, the significance of the role of diasporic poets in developing the body of diverse voices in Iranian women's literary map should be more carefully studied. In a sense, diasporic women's poetry can be considered to be providing an impetus to the process of deconstructing the masculine patterns and conventional paths of morality in Iranian culture. 


\section{REFERENCES}

Afshar, H. (1996). Islam and Feminism: An Analysis of Political Strategies in Yamani, Mai, Feminism \& Islam, Legal and Literary Perspectives. New York University Press.

Hamidpour, R. (2010). Betrayed by Sons of the West, AuthorHouse.

Hosseini, M. (2017). Iranian Women's Poetry from the Constitutional Revolution to the Post-Revolution. Phd thesis.

Ikas, K. and Wagner, G. (2008). Communicating in the Third Space, Taylor \& Francis.

Irigaray, L. (1985). This Sex Which is Not One, Translated by Porter, C. \& Burke, C., Ithaca, Cornell University Press. Irigaray, L. (1985). Speculum of the Other Woman, Ithaca, Translated by Gill, G. C. Cornell University Press.

Irigaray, L. (1993a). An Ethics of Sexual Difference, Ithaca, N.Y., Cornell University Press.

Irigaray, L. (1993b). Je, Tu, Nous, Translated by Martin. A., Routledge.

Milani, F. (1992a). Veils and Words: the Emerging Voices of Iranian Women Writers, Syracuse, N.Y., Syracuse University Press.

Mir-Hosseini, Z. (1999). Islam and gender: the religious debate in contemporary Iran. Princeton, N.J.: Princeton University Press.

Mir-Hosseini, Z. (2005). The Quest for Gender Justice Emerging Feminist Voices in Islam. Reframing Islam. Irish Centre for Human Rights: NUI Galway.

Mir-Hosseini, Z. (2007). The Politics and Hermeneutics of Hijab in Iran: From Confinement to Choice Rights. Muslim World Journal of Human 4. https:/ / doi.org/10.2202/1554-4419.1114

Olson, G. A. and Hirsh, E. (1995) Women Writing Culture, State University of New York Press.

Saffaarzadeh, T. (1979) Harekat va Diruz [Motion and Yesterday], Tehran, Iran, Ravaq.

Shafii, R. (1997). Scent of Saffron. London: Scarlet Press.

Citation: Hosseini, M. (2018). Feminist Culture and Politics in Iranian Women's Post-Revolutionary Poetry (19792017). Feminist Encounters: A Journal of Critical Studies in Culture and Politics, 2(1), 07. https://doi.org/10.20897/femenc.201807

Copyright (C) 2018 by Author/s and Licensed by Lectito BV, Netherlands. This is an open access article distributed under the Creative Commons Attribution License which permits unrestricted use, distribution, and reproduction in any medium, provided the original work is properly cited. 